\title{
EDITORIAL
}

\section{Revenue management - A few new ideas}

Journal of Revenue and Pricing Management (2008) 7, 1-2. doi:10.1057/palgrave.rpm.5160126

There is a growing tendency among consumers to believe they are entitled to have it all and to live life by consuming what we might call 'luxury-snacks'. Luxury has now become so democratic that it is ubiquitously for rent. You can rent a luxury car from Avis, but how about renting the latest couture and designer handbags from www.bagborroworsteal.com. Bag Borrow or Steal was first to market offering the concept of borrowing luxury products and is leading a revolution in the way consumers shop for designer goods or gain access to exclusive events/lifestyles. How much would you pay for a designer hand bag for one or two night usage? You would probably have to pay a premium to use it on Saturday night. 'Quintessentially', an international concierge service and members' club offers customers access to first-class airport lounges, designer fashion shows, nightclubs and exclusive events. How much would you pay for closed to the public for a membership fee ranging between $£ 750$ and $£ 2,500$ ? You can rent a Ferrari or Aston Martin car for an evening from the Classic Car Club. This revenue management model is based upon the number of times you want access or usage, a similar model that is found in the fraction ownership of private jets.

The idea of luxury renting enables customers to 'access the inaccessible'. For both emotional and practical reasons consumers are, on the margins, rejecting owning products in favour of renting them. This development indicates a shift in the consumer mindset towards the ownership of possessions and luxury items. Renting allows consumers to sporadically dip into the luxury lifestyle with- out paying the full (unaffordable for most) price for the privilege. Fractional living like this gives them a chance to adopt an alternative, more glamorous and stylish persona for a short period of time and indulge in celebrity lifestyle - all on a budget.

How would a revenue management model work for taking the stress out of life? Consumers across the world are wishing for less stress and more relaxation. How much would you pay someone to do your work for you in order that you could enjoy 'just for me' moments? One of the biggest trends sweeping Japan presently, are instant detox diets and stress-free weekends, in which highpowered executives escape the maddening crowds of Tokyo for rural settings, in spiritual hotels, where they listen to light music, eat no food, and drink green tea and mineral water. There isn't a blackberry or mobile phone in sight.

Selling rooms by the hour use to be about women of disrepute; however, the Japanesestyle Yotel in London's Gatwick Airport offers luxurious and stylish cabins for rent for travellers with very early departures or who might have a long layover between flights or are delayed for hours. Four hours in a standard cabin costs a very affordable $£ 25$ ( $£ 40$ for a premium cabin). Here you can snooze the hours away comfortably and in style. A similar concept is found in the Vancouver Airport and New York's Empire State Building where MetroNaps operates an urban catnapping business. For $\$ 14$ you can treat yourself to $20 \mathrm{~min}$ in their very futuristic (luxurious) looking sleep pods. 
I wonder how the Revenue Manager for the world's first sea bed hotel will decide the rack rate and the discounting policy. The Poseidon 5 -star hotel, built on the seafloor off the coast of the Bahamas, is ultimate in new experiences. Super luxury 7-star hotels in Dubai now charge visitors just for entering the hotel, as they are the new museums and attractions with some of the finest arts works in the world. Would you pay $£ 100,000$ for a 3 -h flight into outer space, which includes $14 \mathrm{~min}$ of weightless, well according to Virgin Galactic, 500 people for this exclusive experience? After that, the price drops for $£ 25,000$ as the experience becomes less exclusive. Looks like the future is bright for the revenue management industry.

Ian Yeoman Editor 